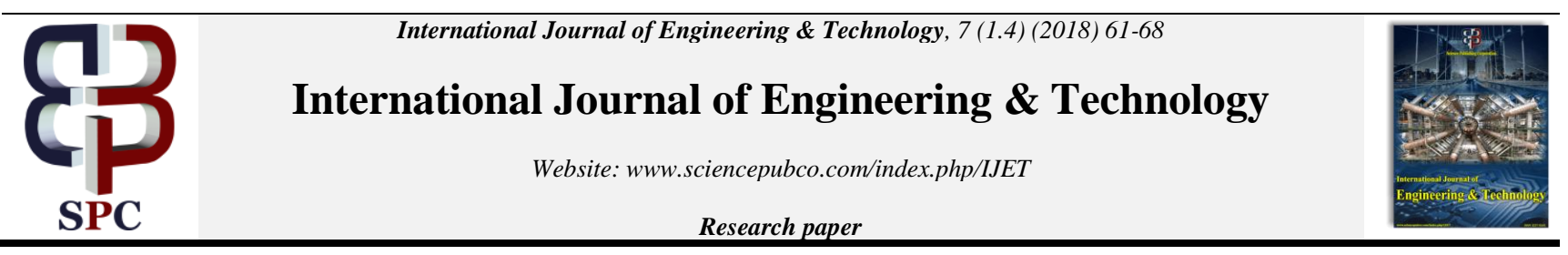

\title{
The urban bioregion as form and project of the co-evolution between urban and rural domain. the case of the Florence metropolitan area
}

\author{
David Fanfani" \\ Architecture Department-DidA, Florence University \\ *Email: david.fanfani@unifi.it
}

\begin{abstract}
Urbanization processes entailed, especially in western countries, growing interaction between urban and rural domain alongside with 'resilience' problems also related to global economic, climate and 'transition' matters. That calls for a 're-embedding' of cities in their surrounding regions. In such a framework, this article explores the opportunity of recovering, in planning practices, the 'urban bioregion' concept, as key feature for balanced and co-evolutionary polycentric urban regions. That allows to point out, as in the case described relatively to Florence MA, the need to adopt integrated and bottom-up approach, in order to overcome routine and path-dependent practices in periurban areas planning.
\end{abstract}

Keywords: Urban Bioregion; Periurban Planning; Agricultural Park; Self-Reliance, Bioregional Economy

\section{Introduction}

The growing difficulties and criticalities stemming from the actual unfair development model could be especially appreciated at regional and local level as a progressive 'de-territorialisation' process $[1,2]$, of the settlements systems from their surrounding regions. Such a process entails, as consequence, weak territories under the ecosystemic point of view as well as amorphous urban regions, depending in a growing rate from external factors especially in exogenous inputs of matter, energy and in defining their own paths and options of local development.

Coping with this problematic context means trying to reframe a 'local development paradigm', encompassing at the same time matters of integrated spatial planning as well as of territory governance. The 'urban bioregion' paradigm $[3,4]$ seems to best fit with this aim and suitable to define the rules for the 'relocalization' [5] for the settlement systems either in spatial/functional as well as in cultural and environmental terms. That especially through the restoring of co-evolutionary relationships between towns and their agri-ecosystemic embedding basins.

2. Settlements transformation processes and problems of regional developments: toward an integrate vision of urban-rural domains

Periodical studies and reports have repeatedly put in clear evidence the strength and pervasiveness of the urbanization process affecting the world population $[6,7]$ with the reaching of the 'threshold' point beyond which the residents in urban domains would have overcome the residents in domains classified as rural.

Such a process, in more specific terms, develops accordingly a twofold, but complementary, direction that sees on one side the polarization of many people in and around some metropolis or 'regional cities' of global level [8. 9] and, on the other side, the growing and continuous urbanization of the countryside at the regional level. That above all with the proliferation of 'low density' dwelling habitats, accordingly to the various urban sprawl forms and patterns [10].

Such a dynamics, beyond reductive interpretations that still propose, at least in spatial terms, a no more heuristic distinction between urban and rural domain, pose, on the contrary, the necessity of a re-interpretation and critical analysis of the new periurban built environments. Actually, in many contexts, it is possible to observe some 'post-metropolitan' horizons and physical assets [11] that ask not only for the use of new spatial and socio-economic analysis categories but even for a analytic and interpretative approach aimed to point out the main generative elements and problematic issues that such a dynamics express.

Particularly a new matter is addressed accordingly with the reinterpretation of the role and very nature of the rural territory and of the agricultural activities carried on there. That especially in relationship to the dense urban environment and to the pressure and functions that the town spreads over the surrounding territory, far beyond its apparent physical borders.

Under this point of view it is worth to recall that some studies and researches present more complex conceptual approaches and 
analysis categories that best fit with the manifold functions, features and roles of the 'intermediate' urban-rural areas. Such a studies, first of all, re-asses the importance of these areas, even in demographic terms, beyond an assumed for granted view of a future of an ineludible 'dominance of the urban'. OECD studies ${ }^{1}$ [12] especially, revising a previous statistical classification, point out on the fact that, intermediate regions classified as 'prevalent rural' and 'rural', still encompass a relevant amount of people that inhabit zones with rural features for which seems necessary to develop appropriate measures and policies.

In such a direction, some further contributions -starting from the observation of the urbanization processes and forms- strongly uphold the calls for a critical revisioning of the epistemological approach in considering the heuristic values of "urban" and "rural" categories as distinct ones $[13,14]$.

In such a direction some other researches, at least at the European level, starting from the awareness of the growing interwoven relationships between urban and rural domain, try to explore -in terms of threats as well of synergies, and opportunities- the new features of the urban/rural domain. Some of these [15]- even recovering less recent contribution concerning the role of the cities in triggering regional development processes [16], conceive the city as 'focus point' for the start up of rural development projects and processes. In such a framework the complementarity between urban and rural is especially expressed in pointing out the role of the periurban regions surrounding the cities as "natural basin of natural resources', for the delivering eco systemic services (ES), and for the enhancement of the natural and cultural heritage in prompting leisure and touristic services and activities.

Although its positive approach, this vision lacks in appreciating the rural areas accordingly a self-reliance prospect in relation to the urban domain and policies. Particularly the main productive role of the periurban areas -the agricultural one- is placed in the framework of a structural/economic 'mainstream' development model that conceive this function as a no more profitable and as residual one, which unique opportunity of survival is not the recovery of a real complementarity with the city (e.g. in the delivering short food chains or in generating new local economies) but a 'passive multifunctionality' at the service of the urban oriented policies, practices and goals.

Some other works are affected by a reductive and 'subsidiary' vision of agriculture in periurban or intermediate areas. Nevertheless they introduce some remarkable features for the conceptual framing and operational deepening of the urban/rural areas role in delivering regional and local development and in pursuing the recovery and improvement of the urban form. In such a direction mentioned OECD reports underline the strategic value of a new urban/rural partnership as key factor for the pursuing of integrated economic development goals. That especially in terms of 'public goods' delivering as basic 'functionings' for the activation of scale economies and policies where the synergy between various economic sector turns out as decisive (e.g. environment quality and resilience, and residents and firms attractiveness, landscape quality and tourism, agriculture and carbon sequestration, food production and proximity markets, etc.).

\footnotetext{
${ }^{1}$ The OECD study, based on EUROSTAT data base, points out as, at european level, population is mainly distributed on areas with rural features, accordingly the following ratios: mainly urban areas $40,3 \%$, intermediate urban-rural areas $35,6 \%$, predominantly rural areas $24,1 \%$. See OECD, 2009, 'Regional typology: Updated statistics', Paris, OECD <www.oecd.org/gov/regional/statisticsindicators>
}

Such a growing awareness, at European level and in spatial policies terms, expresses even in the research network framework ESPON and, more precisely, in the EDORA research project[17]. This last research highlights especially -using some 'metanarrative' as discursive form and assessing the manifold interaction between urban and rural domains- the plurality of 'sociospatial patterns' showed by the various rural contexts and the potentialities that could be enhanced through a stronger integration with the urban domain. Such an approach leads especially to identify the multifunctional relevance of farmland and of farming accordingly with a 'post-productivist' model of 'farming commodification', alternative both to the 'agribusiness' development model (e.g. biofuel production) and to tertiary or secondary activities. This not only in terms of 'public goods' or -better- 'common good production' (e.g. landscape, biodiversity, culture and local knowledge and skills) but for the production of food and service at the (bio)regional level as well. Therefore, even in the EDORA scenario, stands out the call for a new cooperation between urban and rural areas, conceived as basic tool of territorial innovation and local development. Moreover in such a research context is introduced and underlined the 'neo-endogenous development' concept, coherent with the prospect of 're-localization' and enhancement of the local development factors enabling especially local production/consume clusters such as regional 'food-shed' or local food systems [18] local energy systems, districts of fair economics.

\section{From the urban/rural complementarity to the bio-regional co-evolution}

\subsection{Revisioning the approach to urban/rural domains relationships}

The researches and reports above mentioned witness for a progressive development and awareness growth about the pivotal role of rural areas and agriculture in delivering rather basic Ecosystem Services (ES), in triggering local development processes based on 'place specific endowments' not available elsewhere. Nevertheless such a works still remain strongly referred to a model of interpretation of the territorial development processes in which some structural factors of 'distortive' character -caused by the operating power relationships of the market- are not still submitted to criticism.

That leads as consequence that even the primary activity carried on in the rural and 'agriurban' areas- are not reviewed either under the settlement and economic point of view- as active subjects but as endowments at disposal for the urban functions and demands stemmed by the global socio-economic system. For that, for instance, the so-called agriculture 'multifunctionality' could be appraised not so much as acknowledgment of the possible positive collateral results of a peasantry and de-industrialized turn in agriculture [19], but as primary component of the farming revenues. That leaving aside or sometimes neglecting the original farming mission that really consist in producing foods, livestock and fibres maintaining soil fertility and enhancing human and animals wellbeing ${ }^{2}$.

\footnotetext{
${ }^{2}$ Other example of misunderstood collaboration among urban and rural can be that of the search of food of quality from some subjects of the socalled 'critical purchase' domain. In such an approach, the search of a personal benefit (utility) in terms of healthy, food separated by a systemic vision of the food production systems and of its territorial consequences, leads sometimes to ignore the possibilities of collaboration/purchase with the periurban farms because these are see as being too close to the urban area and to its supposed impact.
} 
That kind of consideration leads to develop the hypothesis of the recovery of a form of urban/rural cooperation -focused on the bio-regional paradigm [20, 21, 22] of co-evolution [23] between these two settlement features. That fostering an -above mentionedendogenous development model that, as such, would be rooted on an active role of the territorial local system and not overwhelmed by exogenous factors accordingly with a 'pro-metropolis and antirural hypothesis' [24]. That turns out to be much more relevant considering as, even accordingly the studies above mentioned, the urban and rural dimensions are even more interwoven, despite of the globalization processes themselves, in a complex domain or spatial 'mosaic' of urban/rural interface [25].

Moreover, the recovery of the bioregional paradigm in the context of the agri-urban domain could be supported by the adoption of the joint concept of 'urban bioregion' [26]; conceived as 'cognitive framework' aimed to pursuing a new real 'city/countryside alliance' [27] and based on the recovery of a long period matter/energy cycles regional closure [28], but, even, on the enhancement of the social and cognitive relationship between urban and rural domain accordingly with a vision of a 'single countryside' [29]; a mutuality resulting from the resolved contradiction between nature and culture, leisure and farming activities, market logic and proximity, landscape values and rural exploitation. That especially acknowledging the pivotal role of peri-urban agriculture [30].

Such kind of cooperative model not calls, obviously, for the self-sufficiency of the local territorial systems and of the urban bioregion. It expresses, instead, the self-reliance principle [31] or of self-sustainability [2, cit], as guiding rule inspired to the criteria of fairness, subsidiarity, complementarity/synergy and cooperation between bioregions [32] (see. FIGURE 1. (a), (b)) accordingly with a 'co-evolutionary' and no more 'extractive' view of economic development $[33,34]$. In that the role of the urban fringe and of a new conception of its design and function becomes strategic, especially in order to reshaping the urban form accordingly with a new vision of the public space [35].

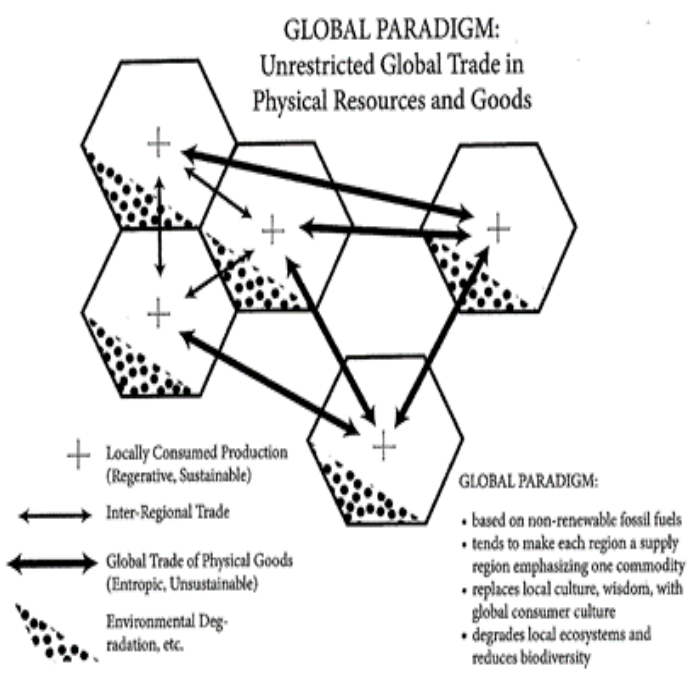

(a)
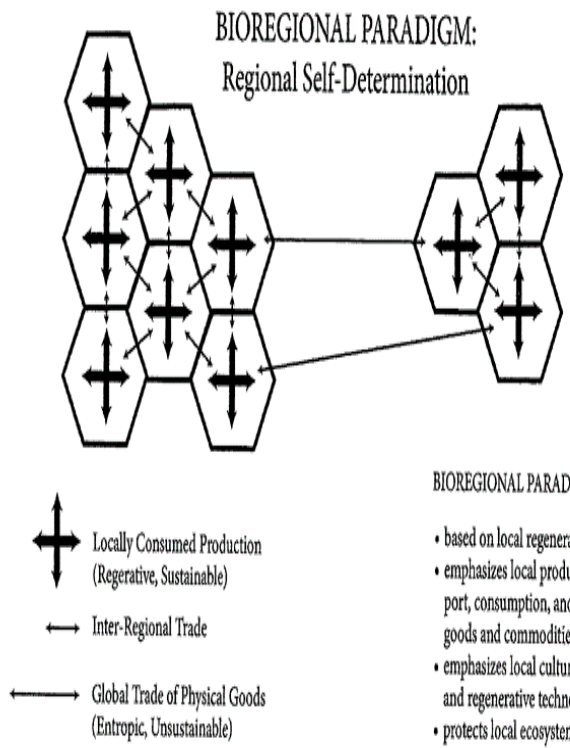

BIOREGIONAL PARADIGM:

- based on local regenerative energy - emphasizes local production, transport, consumption, and recyding of goods and commodities - emplasizes local cullure, wisdom, and regenerative technologies - protects local ecosystems and biodiversity

(b)

Fig. 1 (a),(b): Relational models between regions in local development processes, accordingly with both global and bioregional paradigms (Source, Thayer 2013)

\subsection{Spatial and economic polycentrism of the urban bioregion}

Under the point of view of the settlement form the recovery of the urban bioregion paradigm results in the target of reconstruction of a polycentric settlement model suitable to contain -more than possible- either the energy consuming and globalizing features -both in social and productive terms- of the metropolis form, and, on the other hand, the lost relationship between urban system and environmental structure of the surrounding bioregion. Furthermore, the recovery of the socio-economic and spatial polycentric paradigm must correspond to a proactive relationship between the local bioregional system and the global networks flows, in such a way that the specific territoriality of the urban bioregion could express in an active form [36].

It is worth noting that the recovery of a fair and 'selfsupporting' and 'import replacing' regional economy [16, cit.] calls for the creation of 'selective regional closures' [37] of the regional economy and productive structure in relation to the global system. That in such a way to design and regenerate local productive chains suitable to support a steady relation to the territory either in terms of the local 'grasping' of the 'added value' of the productions issued in the local system and for the regional closure of matter and energy flows

Spatial polycentrism and self-reliance merge then in order to foster a new 'agropolitan' socio-spatial paradigm [38] referred to the urban bioregion model and that, under the point of view of the agri-urban domain, performs accordingly with a co-evolutionary balance between urban centres and surrounding agrienvironmental areas. A balance based on fairness, local participative and deliberative democracy, communitarian resources management and relying on a local market that connects in a selective and active way to the global markets inputs.

Such a theoretical issues, although partially developed in 'global south contexts' are only apparently far from the real dilemmas 
of the ordinary planning practices in western countries. On the contrary, particularly about matters that concerns periurban contexts planning, the principles upheld assume the role of basic reference to overcome the limitations of an 'urban-centric' approach and to reframe the 'mainstream' 'top-down' relationship between local endowments exploitation and driving factors of the global governance for development. That especially in order to pursue the recovery of a 'proximity settlement' form suitable in achieving either balanced economic development and settlement resilience.

Urban bioregion model has still not found applications in ordinary physical planning or in integrated regional development policies. Notwithstanding it is possible to single out, in Europe as elsewhere, some experiences or tools, concerning especially agrienvironmental systems surrounding and penetrating cities, where some of the mentioned principles are proposed and tested. Among these it is possible to point out Periurban Agricultural or rural Parks that, under various modes of kick off, design and management [39], represents a concrete sample of the recovery of a co-evolutionary relationship between human settlements and local environmental features, between nature and culture, accordingly with the Alexander's 'single countryside' pattern image. [29. cit.]. Nevertheless many of these experiences are not exempt by difficulties especially referred to the lack of support on behalf of administrative representatives and private stakeholders. The following paragraph presents the Florence Metropolitan area case, where was triggered a process, mainly -but not exclusively- on behalf of regional government, aimed to design and develop a multifunctional periurban agricultural park. Accordingly with its innovative planning principles and practices ${ }^{3}$, Tuscany Region developed a 'territory integrated project' in a context where it is possible to identify many of the spatial, environmental and socioeconomic issues that call for an integrated recovery of agrienvironmental systems. In this frame the project is aimed to achieve a more resilient and attractive settlement, suitable to foster innovative and self-relied economic development initiatives.

\section{Problems and opportunities for an agropoli- tan local development: the case of the agri- cultural park of the Florence periurban ar- ea}

\subsection{The agriurban domain of the Florence Metropolitan area}

The plain surrounding the west Florence outskirts, with its historical polycentric middle sized urban necklace, represents a paradigmatic context to deal with the matters formerly raised. That especially considering the possibilities and difficulties in order to the recovery of an integrated urban-rural approach to physical

\footnotetext{
${ }^{3}$ Still awaiting for a more general reform of the old framework national urbanism law of 1942, physical planning system in Italy is mainly committed to regional level, and, for binding land use rules, to the municipal one. Some regions, and especially Tuscany among these, have issued spatial planning laws where pivotal is the role - at each level- of territorial long lasting structures, mainly identified with the built environment and natural heritage elements. (Territorial Patrimony and structural invariants). These endowments represent in Tuscany the framing reference for the definition of either municipal land use plan and of strategic spatial projects -either of regional/inter-municipal and municipal scope- lately introduced in the Tuscany regional law. Metropolitan Florence Area Agricultural Park represents a first attempt, promoted by the region itself, to develop in a shared way, this latter design category.
}

planning in a strongly urbanized context that, at the same time, shows all the environmental and resilience problems typical of these areas.

Such area -containing around $1 \mathrm{ml}$ of residents and encompassing beyond 7000 hectares of arable land (excluding hilly areas) could be considered the urban and economic 'engine' of Tuscany (see. FIGURE. 2). Then, considering the strategic role of this area, Tuscany regional administration pursued, since 2007, the practice of a better coordination between the planning goals and action of the various municipality concerned, with the aim of a general improvement of the build environment and metropolitan landscape.

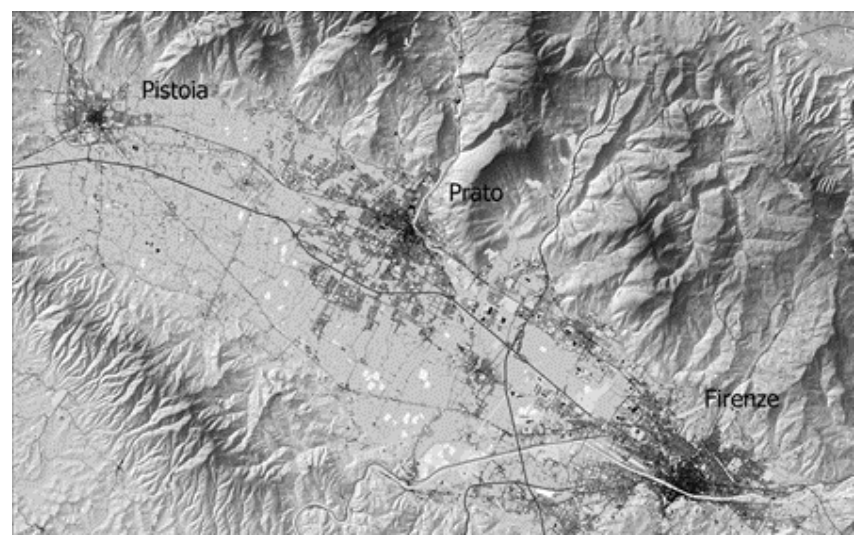

Fig 2: The urban area of the Florence and Prato plain

That in a first phase, for what that concerns the project of a wide multifunctional periurban park in the area, promoting planning agreements and a 'strategic document' (improperly called 'master plan') for the 'Parco della Piana', (see. FIGURE 3). Later on, about the same subject, promoting an innovative planning path for the 'territory project' concerning the creation of this periurban agricultural park with a multifunctional profile aimed to enhance the not negligible archaeological, cultural, environmental and farming 'patrimony' endowments (see. FIGURE.4).

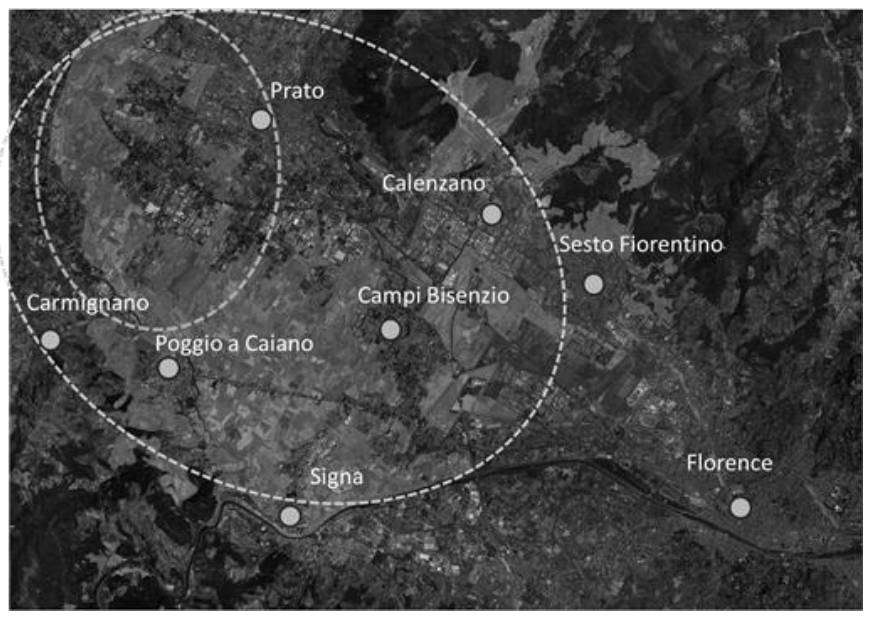

Fig. 3: The agricultural areas of the Metropolitan Florence Area (bright grey) concerned either by the regional prevision of the 'Parco Agricolo della Piana'(Agricultural Plain Park, wider ellipse) and by the process for the creation of the Agricultural Park of Prato (smaller ellipse) 


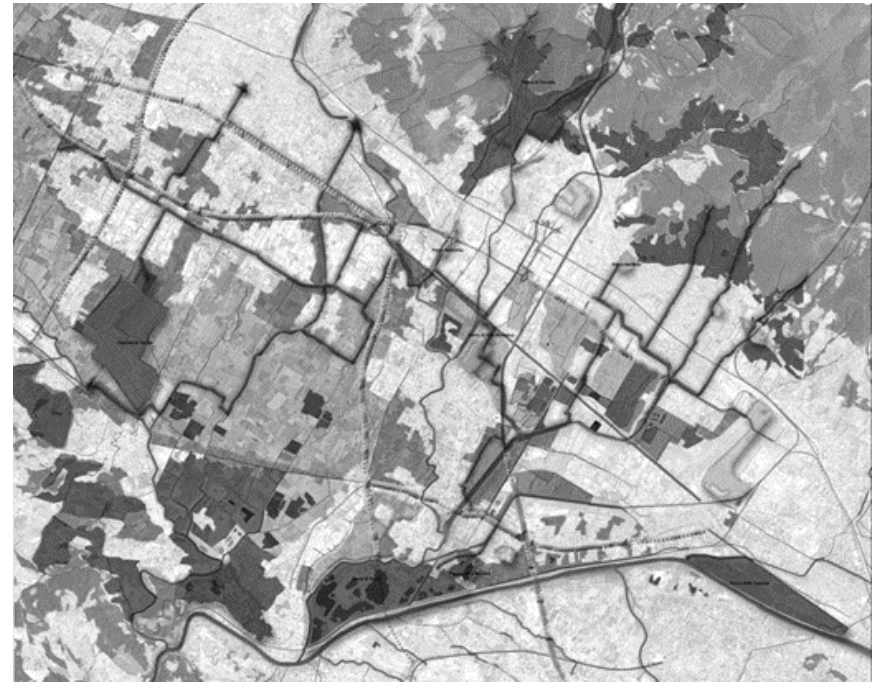

Fig. 4: Design scheme for the Florence plain Agricultural Park: (source Tuscany Region, 2013)

The project, promoted by the urban and regional planning sector of the regional government, has carried on through a process characterized not only by a multilevel and multi sectorial governance approach but, even, with the active involvement of, citizens, associations and stakeholders, that especially promoting public participative tools and forums.

The debate issued by the participative activity and by the project development, was anything but negligible and contributed to the renewal of a general reflection on the metropolitan settlement that interrupted more than ten years ago. Besides, from the outset, with an incremental approach, the planning department of Tuscany Region, prompted some funding channels for the Municipality concerned by the project ${ }^{4}$. That in such a way to allow for a preventive realization of works, 'light' infrastructures and services suitable to anticipate and make visible some park functionings and features.

Although the innovative approach adopted, the project had to cope with some difficulties, to which is due the fact that the project has undergone many delays and it was definitively approved only recently ${ }^{5}$. A first problem stemmed by the difficulties in coordination and collaboration between different sectors of the regional administration and to the weak interest of the agricultural branch toward periurban agriculture and to the project of the periurban agricultural park, perceived, probably, as an 'anomaly' respect to the routine policies in the field of rural development. The other issue, partially related to the first, concerned the partial in volvement of the farmers operating in the area. That was probably a consequence of a scarce habit, on behalf of the farmers, to take part in an active way to participative processes and public debate forums, but even to a scarce awareness of their own role and of the possibility to influence decisional processes usually guided by 'urban reasons'.

Moreover, probably lacked to the regional action the strength and the knowledge base to present the park not only as an environmental compensative or leisure tool, but, even, as a powerful

\footnotetext{
${ }^{4}$ The total economic aid amount, in co.funding forms to the provinces and municipalities, reaches around $16 \mathrm{Mln}$ Euros.

${ }^{5}$ Regional Council Deliberation, n.61, July 16 2014. 'Approbation of the integration to the Regional territorial Plan for the definition of the Plain Agricultural Park and for the qualification of the Florence Airport.
}

and innovative device for local development to set up as a bioregional alternative to other programs still referred to sectorial and top-down approaches. That introduces to the further, and probably more heavy, matter that concerns the delays for the approval of the agricultural park project. Such a matter is referred to the contextual presence, in the administrative document of variation, of the project for the qualification of the Florence Airport, placed in strict closeness to the west Florence outskirt. (see. FIGURE.5). The project of qualification, beyond the logistic and economic matters that it raises up, if realized, would have a heavy impact on the east end of the metropolitan agriurban area and on many environmentally important listed sites. That in such a way to put in discussion not only the -vainly declared in the administrative document- 'framing role' of the park but, as well, the possibility to jointly foster its development and territorial regeneration potentialities $^{6}$.

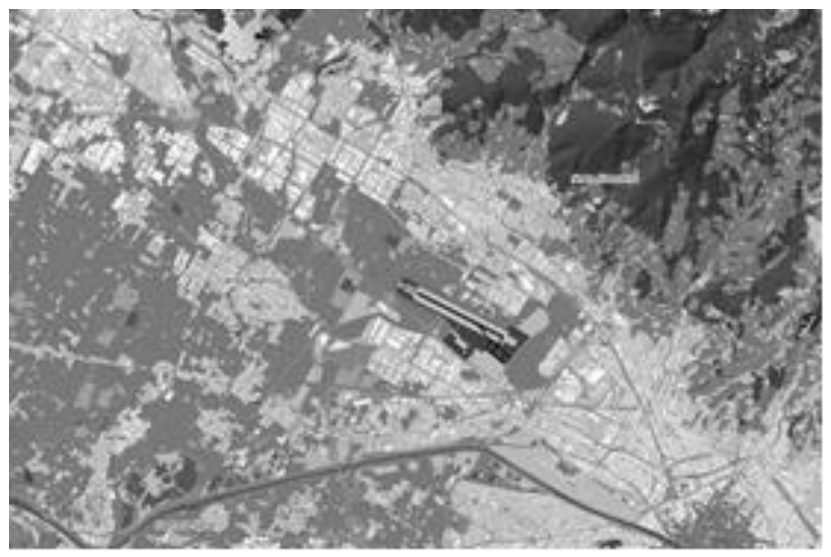

Fig. 5: Position of the new runway foreseen for the Florence Airport in the context of the metropolitan area Florence-Prato (elab. by G.Morone)

\subsection{The process for the Prato Agricultural Park}

Still in the context of the Florence-Prato metropolitan area and alongside with the promotion activities for the Agricultural park before mentioned, starting for a research/action university project, was constituted a local actors 'forum' ${ }^{7}$ for the promotion of an agricultural park in the province and municipality of Prato, (see. FIGURE.3, red ellipse). The forum, following a shared 'protocol of understanding' aimed to the protection of the periurban agricultural areas through the promotion of a proximity and multifunctional farming, developed an 'awareness building' action addressed to citizens and local administrations. Such action, promot-

${ }^{6}$ About some of the main problems of the presumed possible coexistence of the of the park project and of the airport qualification could be helpful to examine the document elaborated by the 'competent authority' in the SEA process called NURV (Regional evaluation nucleus): 'Reasoned advice of the NURV, technical annex c: see <http://www.regione.toscana.it/-/integrazione-al-pit-per-la-definizione-delparco-agricolo-della-piana-e-la-qualificazione-dell-aeroporto-di-

firenze?redirect=http $\% 3 \mathrm{~A} \% 2 \mathrm{~F} \% 2 \mathrm{Fwww}$.regione.toscana.it $\% 2 \mathrm{Fenti}$-eassociazioni\%2Fpianificazione-e-

paesag-

io\%3Fp_p_id\%3D101_INSTANCE_RJ88a5qpXSYL\%26p_p_lifecycle\% 3D0\%26p_p_state\%3Dnormal\%26p_p_mode\%3Dview\%26p_p_col_id\%3 D_118_INSTANCE_cYkX8kKcms47_column-

$1 \% 26$ p_p_col_count $\% 3 \mathrm{D} 1$, last visit, $\overline{10} .10 .2017$

${ }^{7}$ For the forum activities and annexes see: www.parcoagricoloprato.org, last visit,10.10.2017 
ed not only cultural initiatives with seminars and conferences but even developed an intense network activity with local actors.

That even through the constitution of a support group of the 'agri-food sector operators' of the local area, and of a 'technical scientific committee'. The university expertise in the physical planning domain focused especially on the implementation of a design scenario for the Agricultural park of Prato, even in collaboration with some didactic activities (see FIGURE.6). The forum, formalized in 2010 as 'Association for the Agricultural Park of Prato' and gave continuity to the network activity developing some first initiatives for 'food-miles' schemes. That with the aim to demonstrate and verify the viability of 'proximity economies' connected with periurban agricultural exploitation. Economies able not only to pursue environmental sustainability goals but even to maintain an agricultural stewardship, sustainable under the economic point of view, in the framework of a close rural-urban cooperation, especially between farmers and consumers.

The first food miles project has been the creation of a local wheat short food supply-chain that, enhancing a local agri-food cultural and productive craft tradition -the cereals farming and bakery- allows for the networking, in the actual phase of project implementation, of 10 farmers, 10 bakers, a mill and many retail$\mathrm{ers}^{8}$ that produce bread on sourdough exclusively with the use of locally harvested wheat. Peculiar feature of the project is the participate and shared process followed with the local actors involvement, the research of the joint economic affordability for all the participants and the quality and healthiness of the product for the consumers.

The bioregional fairness of the scheme especially for the farmers ${ }^{9}$, could be assumed as an expression of the before mentioned concept of 'selective disconnection' from the global food market [40, 41, 42], allowing for the construction of a bit of a so called 'bioregional justice' [32, cit.]. Furthermore, in economic terms, that schemes assumes the function of a local 'income multiplier', through the local containment of the production-transformation added value and avoiding the 'external leakage' of that value [34 cit., 43]. The project witnesses for the real feasibility of a bioregional shaped economic scheme, especially rooted on the creation of reciprocity relationships between the citizens, protection and valorization of the local resources and heritage, in the framework of urban-rural mutuality.

\footnotetext{
${ }^{8}$ https://granprato.wordpress.com, last visit, 10.10.2017
}

\footnotetext{
${ }^{9}$ The wheat in the short chain is paid to the farmers $38 € / \mathrm{q}$, when, in the ordinary (global)market, the price is usually around $20 €$, but, very often, even less. The bread final price for the consumer is around the same of other quality bread types. $(€ 3 / \mathrm{kl})$.
}

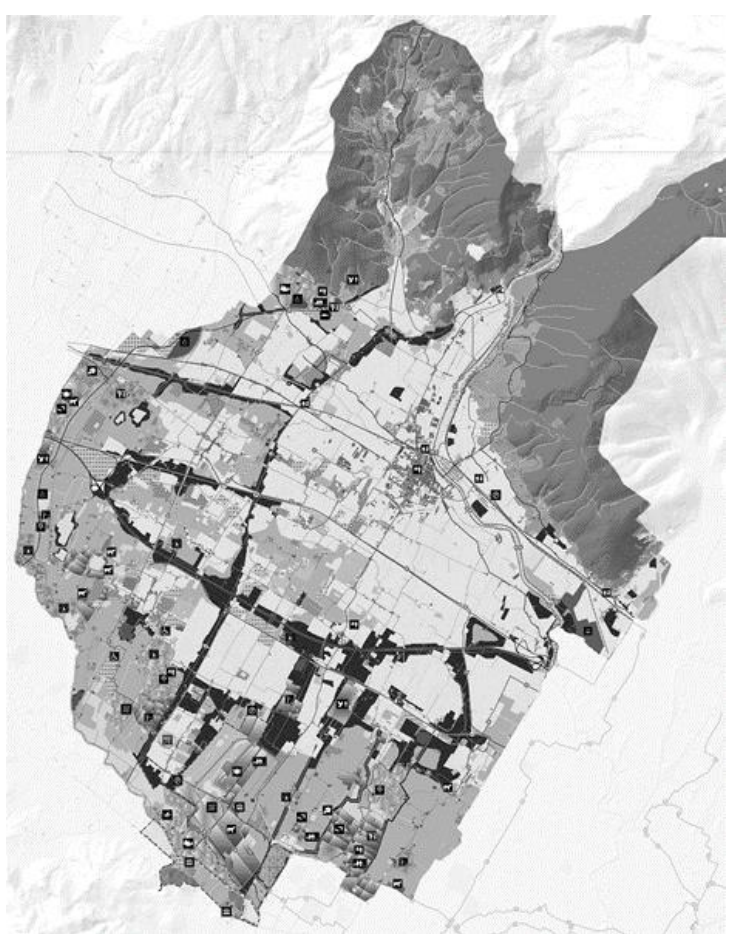

Fig. 6: First spatial scenario scheme for the Prato Agricultural Park (source Mengo, Calvelli, 2008) [44]

Quite similar to the first project, although in a start up phase, is the short-food chain project for the recovery and widening of the breeding of an autochthonous cattle race called 'Calvana' and of a profitable local market for it. Even in this case the association action acted in the contest of a clear 'market failure' in appreciating the biodiversity values and of the limits showed by the public action in dealing with such a failure. The breeding of this cow, not best fitting with the 'law' of the big breeding and retailing system was on the pathway of decline and abandon and the action of the Association was aimed to recovery a 'local' scale market for this cow -the sub-watersheds of Bisenzio and Sieve rivers-, with the involvement of the breeders, butchers and consumers, in such a way to allow for the appreciation of the nutritional quality and value of its meat.

The project, although at the initial stage, has yet proved the feasibility and potentialities of this short food supply chain, that even in recovering the connection between the periurban plain farming system and the hills top pastures of Bisenzio river valley were the cattle are grown in the first phase of their life. Furthermore the recovery of breeding activities regenerates the condition for a multifunctional and organic agriculture and for the ecological and aesthetic regeneration of periurban landscape.

These two cases could appear quite far from the domain of physical planning disciplines but, instead, they show that the design of the urban bioregion cannot be bounded to the consideration of physical/ functional matters ignoring a more general set of conditions, especially related to economic factors, that strongly affect the planning decisions. Infact, as showed by John Friedmann, the agropolitan approach is based on a strong sectorial integration between the main strands of the administration action, especially aimed to the recovery of a synergy between rural development and urban planning policies and tools. That, mainly, in terms of values exchanged between urban residents and farmers, urban activities and agricultural services and products. In this direction the planner role could be conceived as a practitioner able in feeding and framing a 'deliberative and strategic dialogue' between local actors public and private- looking for the best integration and coherence 
between bottom-up development goals and rules and assets for the improvement of an integrated territory design.

\section{Conclusion}

How we've seen the urban area growth implies, paradoxically, some more intense relationships between urban and rural domain, between urban demands and farming activities in agro-urban areas. That, especially, considering the urgent need in achieving settlements sustainability and resilience in the 'transition age' $[45,46$, 47] and the recovery of a co-evolutionary relationship between towns and surrounding environment. The bioregional model and approach can represent a helpful strategic reference in this direction. That, especially, in assuming the prospect for a 'newendogenous approach' $[17$, cit.] as 'key feature' for the local governance, aimed to foster the regional specificity and peculiarities, thanks to the appreciation of some 'intangible' assets (e.g. social capital, trust relationships, government institutions) jointly with some basic heritage 'patrimonial' endowments, as historicalarchitectonical or environmental 'commons'.

That, nevertheless, calls for the adoption of a 'pro-active' habit on behalf of the (new) bioregional communities and the effective promotion of a new integration or agreement between town and countryside [48]. That in order to select especially the exogenous inputs for the local system that, in proposing mainly a 'prometropolis' and urban-focused approach, leads to underestimate the role of periurban areas and agriculture, considered as expressing 'weak powers' or, at best, for their compensative role and not as a key factor in triggering a new sustainable development model. The 'compensative' vision tends, then, to underestimate the systemic and strategic relevance of 'no-market goods' and ecosystem-services [49] that the periurban areas can produce(e.g. fresh food, drinking water, $\mathrm{CO} 2$ sequestration, soil protection, storm water runoff control, etc.) even in generating attractive and thriving places for new residents and activities and in feeding stewardship and place awareness among the inhabitants.

In this context, the planner role could be aimed to review, in critical terms, the needs for the morphological and prestational regeneration of the human settlements [50] conceived as a whole, jointly with the exogenous forces that, often, collide with those needs and tend to reproduce the conditions that it is seeking to fix. In this direction, how we've seen, accounting for the cases of Florence periurban area, is raising as a key issue the construction of collaborative-design settings forums and bottom-up mobilization of local actors and agents. That not only to develop a new awareness about places and territories, but even to cope with some critical points of public governance, still affected, not only in Italy, by a strong sectorial approach and, consequently, unable to deal with multidisciplinary matters typical of edge and periurban contexts. The briefly described experiences show the necessity to gather, in the territory design process, both spatial and physical matters with the contextual experiences and knowledge of local inhabitants and associations. That with the aim to deliver shared and original development visions, although conflicting with 'routine' design and development practices and policies.

\section{References}

[1] Friedmann, J. \& Weaver, C. Territory and function. The evolution of regional planning, Edward Arnold, Chicago , (1979).

[2] Magnaghi, A., Il progetto locale, Torino, Bollati Boringhieri, (2010), (IIth edition reviewed).English translation of first edition,
The Urban villages: a charter for democracy and local selfsustainable, London, Zed Books, (2005).

[3] Atkinsons, A., "The urban bioregion as sustainable development paradigm", Third world Planning review, Vol. 4, No.14, (1992), 327-354.

[4] Allen, A., "Neither rural nor urban: Service delivery options that work for peri-urban poor", McCarney P., Kurian M. (eds.) Periurban Water and Sanitation Services. Policies, Planning and Method, Springer, London, (2010), 27-61.

[5] Thayer, R. L. "The world shrinks the world expands: information, energy and relocalization", Cook, E. \& Lara J.J. (Eds) Remaking metropolis, Milton Park, Abingdon, Routledge, (2013), 39-59

[6] OECD, Regional typology: Updated statistics,(2009), Paris, 240 253, available online: www.oecd.org/gov/regional/statisticsindicators, last visit:10.02.2014.

[7] OECD, Building resilient regions for stronger economies, Paris, OECD Regional Outlook, (2011).

[8] Hall, P. \& Pain, K. (Eds), The Polycentric Metropolis. Learning from Mega-City Regions in Europe, London, Earthscan, (2006)

[9] Sassen, S. Cities in a world economy, Los Angeles, Sage, (2004)

[10] European Environment Agency (EEA), Urban sprawl in Europe. The ignored challenge, EEA Report, (2006), available online: http://www.eea.europa.eu/publications/eea_report_2006_10, last visit: 09.02 .2015

[11] Soja, E., Postmetropolis: Critical Studies of Cities and Regions, Oxford, Blackwell Publishers, (2000).

[12] OECD, Rural-Urban partnership, an integrated approach to economic development, Paris, OECD, (2013).

[13] Brenner N., Schmid C., "The 'urban age' in question", International Journal of Urban and Regional Research, Vol.38, No. 3 , (2014), 731-755.

[14] Brenner N., Schmid C., "Towards a new epistemology of the urban?", City, Vol. 19, No. 2-3, (2015), 151-182.

[15] Van Leuven, E., Rural-Urban integration; town as focus point in rural development, Dordrecht, Springer-Verlag, (2010).

[16] Jacobs, J., Cities and the wealth of nations. Principles of economic life, New York, Random House, (1984).

[17] ESPON, EDORA, European development opportunity for rural areas. Final report, (2013).

[18] European Regions Commitee (ERC), Opinion on Local Food Systems, (2011/C 104/01), (2011): available online: http://eurlex.europa.eu/LexUriServ/LexUriServ.do?uri=OJ:C:2011:104:000 1:0006:EN:PDF, 2015), last visit: 09.02.2015.

[19] Van der Ploegh J.D.,The New Peasantries. Struggles for Autonomy and Sustainability in an Era of Empire and Globalization, London, Earthscan, (2008).

[20] Sale, K., Dwellers in the land: The bioregional vision, San Francisco, Sierra Club book, (1985).

[21] Thayer, R.L., LifePlace, Bioregional Thought and practice, Berkeley, California University Press, (2003),

[22] Magnaghi, A., La bioregion urbaine. Petit traité sur le territoir bien commun, Paris, Eterotopia, (2014).

[23] Geddes P., Cities in Evolution. London, Williams \& Norgate, (1915).

[24] Douglass, M., “A regional network strategy for reciprocal ruralurban linkages: an agenda for policy research with reference to Indonesia", Third World Planning Review, Vol.1, No. 20, (1998), 133.

[25] Allen, A., "Environmental planning and management of the periurban interface: perspectives on an emerging field",Environment and urbanization, Vol. 15, (2003), 135-147, Available Online: http://eau.sagepub.com/content/, last visit: 09.02.2015.

[26] Atkinsons, A., "The urban bioregion as sustainable development paradigm", Third world Planning review, Vol. 4, No.14, (1992), 327-354.

[27] Magnaghi, A. \& Fanfani, D. (eds), Patto città campagna. Un progetto di bioregione urbana per la Toscana centrale, Firenze, Alinea, (2010).

[28] Jancovici J.M., Transition énergetique pour tous. Ce que les politiquesn'osent pas vous dire, Paris, Odile Jacobs, 2011.

[29] Alexander C., "The Countryside", in A Pattern language. A timeless way of building, Oxford (Mass), Oxford University Press, (1977), 36-39.

[30] European Economic Social Committee (EESC) Opinion on Agriculture in Periurban Areas, NAT/204, Brussels, (2004), available online: http://www.agroterritori.org/web2/wpcon- 
tent/uploads/2014/05/EESC_opinion_agriculture_periurban_areas. pdf,, last visit: 09-02.2015.

[31] Scott Cato M., The bioregional economy, Land, liberty and the pursuit of happiness, London, Routledge, (2013).

[32] Pezzoli, K., "Bioregional justice: a framework for ecological restoration", (draft statement prepared for the good neighbour environmental board), San Diego, Cal., Global Action Research Centre,. (2013), 1-7, available online: http://test-

super-

fund.gotpantheon.com/sites/default/files/Bioregional_Justice_Pezz oli_May20-2013.pdf: last visit: 10.02.2015.

[33] Noorgard, R.B., Development betrayed, the end of progress and a coevolutionary revisioning of the future, London, Routledge,(1994).

[34] Power, T.M., Lost landscapes and failed economies. The search for a value of place, Washington, D.C., Island Press, (1996)

[35] Poli D., "Pianificazione paesaggistica e bioregione: dalle regole statutarie alle norme figurate", Magnaghi, A. (ed) La regola e il progetto. Un approccio bioregionalista alla pianificazione territoriale, Firenze, Firenze University Press, (2014), 97-126.

[36] Dematteis, G., "Per una geografia della territorialità attiva e dei valori territoriali", Bonora, P. (Ed) SLoT, Quaderno1, Bologna, Baskerville, (2001), 11-30.

[37] Stöhr W.B., Thödling, "Spatial equity-Some Anti-theses to current regional development doctrine", Regional Sciences, Vol.38, No.2, (1977), 33-53.

[38] Friedmann, J. \& Weaver, C. Territory and function. The evolution of regional planning, Edward Arnold, Chicago , (1979).

[39] Fanfani, D., Pianificare fra città e campagna. Scenari, attori e progetti di nuova ruralità per il territorio di Prato, Firenze, Firenze University Press, (2009).

[40] Morgan, K., "Feeding the city: the challenge of urban food planning", International Planning Studies, Vol.4, No. 14, (2009), 341348, available online: http://dx.doi.org/10.1080/13563471003642852, last visit 15.01.2014.

[41] Morgan, K. \& Sonnino, R. "The urban foodscape. World cities and the new food equation", Cambridge Journal of Regions, Economy and Society, Vol.3, No.2, (2010), 209-224.

[42] Marino, D., Cicatiello, C. (Eds), Farmer's markets, la mano visibile del mercato. Aspetti economici, sociali e ambientali delle filiere corte, Milano, Franco Angeli, (2013).

[43] Dwarshuis-Van de Beek, L., "Local Food systems", Presentation for the International meeting of Rururbal Project, The agri-food local systems and the new European policies,(2011), available online: http://www.diba.cat/web/cjs/inici/-/cjs/1567, last visit: 05.01.2015.

[44] Calvelli G., Mengo M. Politiche e piani per il territorio periurbano, scenario progettuale per il Parco agricolo della piana di Prato. (Undergraduate degree dissertation), Florence University, (2008)

[45] Hopkins, R. The transition Handbook. From oil dependency to local resilience, Vermont, Chelsea Green Publishing, (2008)

[46] Newman, P. "A vision for resilient cities", Resilient cities. Responding to peak oil and climate change, Island Press, Washington D.C. (2009), ,55-85.

[47] Wilson, E., Piper, J., Spatial Planning and Climate change, New York, Routledge, (2010).

[48] Iacoponi L., "La complementarità fra città e campagna per lo sviluppo sostenibile: il concetto di Bioregione", Rivista di economia agraria, Vol. 4, No. LIX, (2004), 443-475.

[49] Rovai, M., Di Iacovo, F. \& Orsini, S., "Il ruolo degli ecosystem services nella pianificazione territoriale sostenibile", Perrone, C. , Zetti, I. (Eds) Il valore della terra. Teoria e applicazioni per il dimensionamento della pianificazione territoriale, Milano, Franco Angeli, (2009), 135-162.

[50] Lynch, K., Good City Form, Cambridge (Mass), Cambridge University Press, (1984). 